\title{
Factors Affecting Academic Performance of First-Year Business Education Students in Ekiti State College of Education
}

\author{
Ogunleye, W. A ${ }^{1} \quad$ Ocholi, J. M ${ }^{2} \quad$ Garuba, O.L ${ }^{2} \quad$ Folmi, D.P ${ }^{2}$ \\ 1.Department of Vocational and Technical Education, Faculty of Education, Ekiti State University, Ado Ekiti, \\ Ekiti State, Nigeria \\ 2.Department of Office Technology and Management, Abubakar Tatari Ali Polytechnic, Baushi, Baushi State,
} Nigeria

\begin{abstract}
The study examined factors affecting the academic performance of first-year Business Education students in the College of Education Ikere Ekiti. The study adopted the descriptive research design of a survey type. The population of the study consists of 374 Business Education students. Sample of 150 students was selected using a simple random sampling technique. Questionnaire was the instrument used for the study. The validity and reliability of the instrument were ensured. The reliability coefficient of 0.90 was obtained using the Cronbach alpha coefficient which indicated that the instrument was reliable to collect the necessary data for the study. Data were analyzed using descriptive statistics of mean and standard deviation. The study concluded that various factors are causing poor academic performance of first-year Business Education students in the College of Education, Ikere Ekiti. These include course structure, poor students academic background, inadequate teaching and learning resources, lack of reading habit and reading plan of students, a bridge between theory and practical, lecturers' pedagogical knowledge and skills, lecturers' professional knowledge, quality of available lecturers, boring lectures presentations method among others. Therefore, to reduce poor students' academic performance, the study recommends that all the measures revealed in the study should be implemented in order to ensure better students' academic performance. Also, the Business Education syllabus should be re-designed and implemented to meet today's needs. Finally, lecturers should be given proper guide and encouragement to students to make them happy for them not to lose hope towards the study of Business Education in Tertiary institutions
\end{abstract}

Keywords: Tertiary Institutions, Business Education, Students, Academic Performance

DOI: $10.7176 / \mathrm{JEP} / 11-35-07$

Publication date: December $31^{\text {st }} 2020$

\section{Introduction}

Business Education is one of the courses offered in tertiary institutions like the College of Education and Universities in Nigeria. This course was designed in a theoretical and practical oriented way to provide individuals with skills in business-related occupations such as accounting, office occupation, and marketing. The course aims to equip the student with the relevant practicable skills that would make them self-reliant in the areas of accounting, OTM, and marketing after graduation. Etonyeaku and Anyanwu (2012) opined that Business Education is concerned with the areas of knowledge and competencies needed by individuals such as skills, abilities, understanding, and attitudes that would enable students to become a worthy human being and to be effective in society. Because of that, the performance of Business Education students becomes the center of focus of guardians, relatives, teachers, and different partners since it decides understudies' viability.

The academic performance of students is an aspect of the educational system through which their knowledge, ability, and quality of students are measures. Academic success is highly instrumental to the political, social, and economic development of a nation. Ali et al., cited by Irfan and Shabana (2012), affirmed that producing quality graduates who would become great leaders and work for the country as well as responsible for the countries economic and social development make student's academic performance in education essential. Osaikhiuwu (2014) believed that producing competent, skilled, and employable graduates is a testimony of institutional effectiveness. Students' academic performance, according to Steinmayr et al. in Omachonu, and Akanya, (2019) is the outcomes that show the extent to which a learner has accomplished specific goals in instructional environments.

Despite the nature of Business Education, the academic performances of students are not still encouraging. Jayanthi et al. (2014) and Bolton (2019) believed that the poor students' academic performance is associated with attrition, reduced graduate output, and an increased cost of education. Poor academic performance of first-year students is the lack of fundamental understanding of their course because many students lacked adequate knowledge of the fundamental principles underpinning their study (Rollnick et al., 2008; Marais \& Mji, 2009; Steenkamp et al., 2009). In another vein, the poor academic performance of first-year students attributed to unrealistic beliefs about class sizes, staff availability, and workload (Lowe \& Cook, 2003; Smith, and Hopkins, 2005; Crisp et al., 2009; Kandinko \& Mawer, 2013; Hassel \& Ridout, 2018).

Hien Thu Thi Le et al. (2020) conducted similar research on factors affecting the academic performance of first-year university students at Vietnamese University, Hanoi. They categorized the factors that affect students' 
academic performance of first-year University students into five. These include motivation of students, lecturers' pedagogical knowledge and skills, lecturers' professional knowledge and credential, learning resources and conditions, and course structure. Crosnoe, Johnson, and Elder, cited by Olatunji, Aghimien, Oke, and Olushola (2016), identified some factors that are affecting student's academic performance. These include fear, uneasiness, certainty, fixation, wellbeing, and prosperity. They further that social factor is likewise impacting the scholarly presentation of understudies like the companion gathering, family foundation, religion just as family emergency. Authors further revealed other variables infrastructures for learning, monetary variables, money related issue, and stress; natural factors, for example, learning climate, class size, and condition, for example, (locality crisis, noise pollution), teaching and training techniques; personal factors among students like lack of reading habit and reading plan, unwillingness to assume full responsibility, procrastination, attitude towards school, lack of initiative and use of imagination, playing and wasteful time spending, interest in a course, absence of self-restraint, proficiency abilities of students, absence of development, absence of want, choice, and assurance, sluggishness or detachment, and poor exam preparation (fire brigade approach).

Finally, they identified academic factors such as lack of provision of a bridge between theory and practical and heavy course workload for students. Killen et al. cited by Iwu, Benedict, and Sibanda (2015), found the following factors that are strongly influencing undergraduates' academic performance. These include motivation, students, time management skills, cultural expectations, psychological factors, student academic literacy, peer culture, the quality of teaching as well as student approach towards study, the belief of students in their ability, and student support structures offered by the institution. It is against this background the study now adopts some variables in Crosnoe, Johnson, and Elder, cited by Olatunji, et al. (2016), Hien Thu Thi Le et al. (2020) and other previous studies to determine factors affecting first-year Business Education students in Ekiti state College of Education.

\section{Statement of the Problem}

Poor academic performance has been the issue of debate among researchers over the years that what exactly could cause the poor academic performance of students, especially in tertiary institutions. Despite research carried out to establish this fact, poor academic performance has not changed is even worse than ever before. The issue has made individuals question standard of tertiary instruction in Nigeria. The question is that could we trace this problem to the number of lecturers available, lecturer pedagogical knowledge and skills, learning facilities, course structure, parental supports, student academic background, lack of time management skills, and student learning motivation (DeBerard et al. 2004; Vasconcelos \& Almeida 2018, \& Hien et al., 2020). The findings of Ephraim (2004) found that most of the public institutions in Nigeria have high enrolments without enough qualified lecturers that resulted in the worsened situation of staff/student ratio that detriment to student performance and academic research.

Okolie et al. (2014) stressed that parental help and kind of nurturing single or two nurturing framework represented variety in understudies' scholastic exhibition and furthermore that instructive achievement relies upon the financial status of guardians. Teaching and learning facilities are other factors given by Osuji (2016), who identified that inadequate facilities affect teaching, learning, mental stability, inter-personal relationship as well as the psychomotor domain of the students. He furthers that the absence of quality educational facilities affects teaching and learning activities and invariably academic performance of students. Based on the previous works and for the fact that higher educational institutions in the world recognized that first-year students should be the prime focus of any retention strategy (Meer, Scott \& Pratt, 2018). Therefore, this study now adopted some variables in the previous studies to determine factors affecting the academic performance of first-year business education students in Ekiti state College of Education.

\section{Purpose of the Study}

This study examined factors affecting the academic performance of first-year Business Education students in the College of Education Ikere Ekiti. Specifically, the study would:

1. examine the key factors that affect the academic performance of first-year Business Education students

2. identify the measures to be adopted to reduce Business Education student's poor academic performance

\section{Research Questions}

The following two research questions were raised to guide the study

1. What are the key factors affecting the academic performance of first-year Business Education students?

2. What are the measures to be adopted to reduce Business Education students' poor academic performance?

\section{Methodology}

The study adopted a descriptive research design of a survey type. The population of the study consists of 374 Business Education students in the College of Education, Ikere Ekiti. The sample of the study was 150 students 
selected using a simple sampling technique. A well-structured questionnaire was the instrument used for the study and validity of the instrument was ensured for the face structure by two experts. The reliability of the instrument was determined through a pilot-test conducted on the instrument. The reliability coefficient of 0.90 obtained using the Cronbach alpha coefficient which indicated that the instrument was reliable to collect the necessary data for the study. Data were analyzed using descriptive statistics of mean and standard deviation.

Results
Descriptive Analysis
Table 1: Mean Score and Standard Deviation on Factors Affecting Academic Performance of First-Year
Business Education Students
\begin{tabular}{|l|l|l|l|l|l|}
\hline S/N & ITEMS & N & Mean & St.D & Rank \\
\hline 1 & Course structure i.e too much course workload for students & 150 & 3.48 & 0.939 & $1^{\text {st }}$ \\
\hline 2 & Poor academic background of students & 150 & 3.41 & 0.883 & $2^{\text {nd }}$ \\
\hline 3 & $\begin{array}{l}\text { Inadequate students' knowledge of the fundamental principles } \\
\text { underpinning the course of study }\end{array}$ & 150 & & & $3^{\text {rd }}$ \\
\hline 4 & Inadequate teaching resources/facilities & 150 & 3.10 & 1.246 & $4^{\text {th }}$ \\
\hline 5 & Lack of quality learning resources/facilities & 150 & 3.08 & 1.217 & $5^{\text {th }}$ \\
\hline 6 & Lack of reading habit and reading plan of students & 150 & 3.04 & 1.140 & $6^{\text {th }}$ \\
\hline 7 & Lack of provision of a bridge between theory and practical & 150 & 3.02 & 1.158 & $7^{\text {th }}$ \\
\hline 8 & Lecturers' pedagogical knowledge and skills & 150 & 2.91 & 1.214 & $8^{\text {th }}$ \\
\hline 9 & Lecturers' professional knowledge & 150 & 2.88 & 1.150 & $9^{\text {th }}$ \\
\hline 10 & Quality of available lecturers & 150 & 2.82 & 1.153 & $10^{\text {th }}$ \\
\hline 11 & Boring lectures presentations method employed by the lecturers & 150 & 2.81 & 1.178 & $11^{\text {th }}$ \\
\hline 12 & Unwillingness to assume full responsibility by students & 150 & 2.75 & 1.146 & $12^{\text {th }}$ \\
\hline 13 & Inappropriate and biased assessment procedures used by lecturers & 150 & 2.75 & 1.214 & $13^{\text {th }}$ \\
\hline 14 & Poor Time management skills among students & 150 & 2.74 & 1.101 & $14^{\text {th }}$ \\
\hline 15 & Students academic literacy level i.e ability to read and write & 150 & 2.72 & 1.129 & $15^{\text {th }}$ \\
\hline 16 & Poor preparation for exam (fire brigade approach) & 150 & 2.64 & 1.082 & $16^{\text {th }}$ \\
\hline 17 & Financial problem and additional financial stress for students & 150 & 2.63 & 1.064 & $17^{\text {th }}$ \\
\hline 18 & Imbalances between academic commitment and social life & 150 & 2.45 & 1.126 & $18^{\text {th }}$ \\
\hline 19 & Psychological factors such as food e.t.c & 150 & 2.44 & 1.064 & $19^{\text {th }}$ \\
\hline
\end{tabular}

The result in table 1 shows the factors affecting academic performance of first-year Business Education students. The mean and standard deviation scores revealed that course structure i.e too much course workload for students $(\mathrm{M}=3.48 ; \mathrm{SD}=.939)$ is ranked first among the factors affecting academic performance of first-year Business education students. This is closely followed by poor academic background of students $(\mathrm{M}=3.41 ; \mathrm{SD}=$ $0.883)$, inadequate students' knowledge of the fundamental principles underpinning the course of study $(\mathrm{M}=3.11$; $\mathrm{SD}=1.201)$, inadequate teaching resources/facilities $(\mathrm{M}=3.10 ; \mathrm{SD}=1.246)$, lack of quality learning resources/facilities $(\mathrm{M}=3.08 ; \mathrm{SD}=1.217)$, lack of reading habit and reading plan of students $(\mathrm{M}=3.04 ; \mathrm{SD}=$ $1.140)$, lack of provision of a bridge between theory and practical $(\mathrm{M}=3.02 ; \mathrm{SD}=1.158)$, lecturers' pedagogical knowledge and skills $(\mathrm{M}=2.91 ; \mathrm{SD}=1.214)$, lecturers' professional knowledge $(\mathrm{M}=2.88, \mathrm{SD}=1.150)$, quality of available lecturers $(\mathrm{M}=2.82 ; \mathrm{SD}=1.153)$, boring lectures presentations method employed by the lecturers $(\mathrm{M}$ $=2.81 ; \mathrm{SD}=1.178)$, unwillingness to assume full responsibility by students $(\mathrm{M}=2.75, \mathrm{SD}=1.146)$, inappropriate and biased assessment procedures used by lecturers $(\mathrm{M}=2.75 ; \mathrm{SD}=2.14)$, poor time management skills among students $(\mathrm{M}=2.74 ; \mathrm{SD}=1.101)$, students academic literacy level i.e ability to read and write $(\mathrm{M}=2.72 ; \mathrm{SD}=$ $1.129)$, poor preparation for exam (fire brigade approach) $(\mathrm{M}=2.64 ; \mathrm{SD}=1.082)$, financial problem $(\mathrm{M}=2.63$; $\mathrm{SD}=1.064)$, imbalances between academic commitment and social life $(\mathrm{M}=2.45 ; \mathrm{SD}=1.126)$, and psychological factors such as food e.t.c $(\mathrm{M}=2.44 ; \mathrm{SD}=1.064)$. The results indicated that first year Business Education students revealed their poor academic performance are caused by the various factors in the table 1 . 
Table 2: Mean Score and Standard Deviation on the Measures to be adopted to Reduce Business Education Student's Poor Academic Performance

\begin{tabular}{|l|l|l|l|l|l|}
\hline S/N & ITEMS & N & Mean & St.D & Remarks \\
\hline 1 & Dynamic methods of teaching to impact knowledge and skills & 150 & 3.21 & 0.616 & Agreed \\
\hline 2 & $\begin{array}{l}\text { Professional training and retraining of lecturers to improve their } \\
\text { professional knowledge }\end{array}$ & 150 & 3.37 & 0.798 & Agreed \\
\hline 3 & Employment of adequate and qualified lecturers & 150 & 3.42 & 0.707 & Agreed \\
\hline 4 & $\begin{array}{l}\text { Provision of adequate teaching and learning resources/facilities } \\
\text { Reduction and restructuring of course workload (i.e courses) } \\
\text { offering by the students }\end{array}$ & 150 & 3.16 & 0.751 & Agreed \\
\hline 6 & $\begin{array}{l}\text { Students willingness to assume responsibility such as reading, } \\
\text { assignment, attendance e.t.c }\end{array}$ & 150 & 3.34 & 1.265 & Agreed \\
\hline 7 & $\begin{array}{l}\text { Effective training and retraining programmes for academic staff by } \\
\text { government }\end{array}$ & 150 & 2.79 & 0.756 & Agreed \\
\hline 8 & $\begin{array}{l}\text { Regular and comprehensive evaluation feedback on progress and } \\
\text { teaching effectiveness of lecturers }\end{array}$ & 150 & 3.21 & 0.879 & Agreed \\
\hline 9 & $\begin{array}{l}\text { Proper guide and encouragement of students towards learning by } \\
\text { lecturers to enhance their ability and competences }\end{array}$ & 150 & 3.39 & 0.865 & Agreed \\
\hline 10 & Adequate provision of conducive learning environment & 150 & 3.35 & 0.603 & Agreed \\
\hline 11 & Adequate provision of bridge between theory and practical & 150 & 2.96 & 0.722 & Agreed \\
\hline 12 & Appropriate choice of course of study among students & 150 & 2.89 & 0.898 & Agreed \\
\hline 13 & $\begin{array}{l}\text { Adequate institution syllabus contents for Business Education } \\
\text { students }\end{array}$ & 150 & 3.08 & 0.690 & Agreed \\
\hline 14 & $\begin{array}{l}\text { Adequate implementation of institution syllabus for teaching } \\
\text { students }\end{array}$ & 150 & 2.95 & 0.789 & Agreed \\
\hline & Grand mean and standard deviation & & 3.16 & $\mathbf{0 . 8 0 1}$ & Agreed \\
\hline
\end{tabular}

The result from table 2 showed that all the items are rated above the acceptable mean score of 2.50 which indicating agreement with all the statements. The grand mean and standard deviation of 3.16 and 0.801 further revealed that there was a strongly agreed reaction from the respondents on all the statements. These results showed that the majority of the respondents agreed that all the statements are the measures that could be adopted to reduce the poor academic performance of first-year Business Education students.

\section{Discussion of Findings}

The result of findings of the study indicated some factors that are causing poor academic performance of first years Business Education students. These include course structure i.e too much course workload for student's, poor students academic background, inadequate students' knowledge of the fundamental principles underpinning the course of study, inadequate teaching and learning resources/facilities, lack of quality learning resources/facilities, lack of reading habit and reading plan of students, a bridge between theory and practical, lecturers' pedagogical knowledge and skills, lecturers' professional knowledge, quality of available lecturers, boring lectures presentations method, unwillingness to assume full responsibility by students, inappropriate and biased assessment procedures used by lecturers, poor time management skills among students, students academic literacy level i.e ability to read and write, fire brigade approach, financial problem, imbalances between academic commitment and social life, and psychological factors such as food. This supported the findings of Rollnick et al., (2008), Marais and Mji, (2009), Steenkamp et al., (2009), Iwu et al., (2015), Olatunji et al., (2016), Osuji (2016), and (Hien Thu Thi Le et al., 2020).

The study also revealed measures that could be taken to reduce the poor academic performance of first-year Business Education students, these include; dynamic methods of teaching, professional training and retraining of lecturers, employment of adequate and qualified lecturers, provision of adequate teaching and learning resources, reduction and restructuring of students course workload, regular and comprehensive evaluation feedback on progress and teaching effectiveness of lecturers from students, provision of conducive learning environment, adequate provision of bridge between theory and practical, adequate institution syllabus contents and implementation of syllabus for teaching Business Education students.

\section{Conclusion and Recommendations}

In conclusion, based on the findings of this study, the study concluded that there are various factors causing poor academic performance of first-year Business Education students in the College of Education Ikere Ekiti. Nineteen factors were revealed in the study. To reduce poor student's academic performance, the study recommends that all the measures revealed in the study should be implemented in order to ensure better students' academic performance. 
Also, the Business Education syllabus should be re-designed and implemented to meet today's standards. Finally, lecturers should be given proper guide and encouragement to students to make them happy for them not to lose hope towards the study of Business Education in Tertiary institutions.

\section{References}

Bolton, R., (2019). Schools not preparing students for university or work. Financial Review: 1. Retrieved from https://www.afr.com/policy/health-and-education/schools-not-preparing-students-for-university-or-work20190614-p51xra

Crisp, G., E. Palmer, D. Turnbull, T. Nettelbeck, L. Ward, A. LeCouteur, A. Sarris, P. Strelan \& L. Schneider, (2009). First year student expectations: Results from a university-wide student survey. Journal of University Teaching and Learning Practice, 6(1), 11-26.

DeBerard, M.S., Spielmans, G.I. \& Julka, D.L. (2004). Predictors of Academic Achievement and Retention among College Freshmen: A longitudinal study. College Student Journal, 38(1), 66-81.

Ephraim, E. O. (2004). Research and Technological Development in Nigeria. Available: http://les.man.ac.u $\mathrm{k} / \mathrm{prest} / \mathrm{SCOPE} /$

Etonyeaku, E.A.C. and Anyanwu, J.C. (2012) Vocational Business and Counceling: Panacea for Achieving Sustainable Poverty Reduction and Wealth Creation. Nigeria Journal of Vocational Association (NVAJ), 17, 139-147.

Hassel, S. \& N. Ridout, 2018. An Investigation of First-Year Students' and Lecturers' Expectations of University Education. Frontiers in Psychology, 8(2218), 1-13.

Hien T. T., Hang ,T. T. N, Thuy, P. L, Trinh, T. T.L., Nguyen, N. T., Tram, P. T. N., \& Trung Tran (2020). Factors Affecting Academic Performance of First-Year University Students: a case of a Vietnamese University. International Journal of Education and practice 8(3) 221-232.

Iwu, C.G., Benedict, O.H., Sibanda, L. (2015). Factors Influencing Academic Performance of University Students. Demography and Social Economy 2(24) 103- 115

Jayanthi, S.V., Balakrishnan, S., Ching, A.L.S.,. Latiff, N.A.A \& Nasirudeen, A. (2014). Factors Contributing to Academic Performance of Students in a Tertiary Institution in Singapore. American Journal of Educational Research, 2(9), 752-758.

Kandinko, C.B. \& Mawer, M. (2013). Student Expectations and Perceptions of Higher Education. A study of UK higher education commissioned by the quality assurance agency. London: King's Learning Institute.

Lowe, H. \& Cook, A. (2003). Mind the gap: Are students prepared for higher education? Journal of Further and Higher Education, 27(1), 53-76.Available at: https://doi.org/10.1080/0309 770305629.

Marais, F. \& Mji, A. (2009). Factors Contributing to Poor Performance of First year Chemistry Students. Pretoria, South Africa: Tshwane University of Technology.

Okolie U. C., Inyiagu E. E., Elom E. N., Ndem J. U. \& Nwuzo A. C. (2014). Effect of Home Background on Academic Performance of Technical College Students in Ebonyi State, Nigeria. The International Journal of Humanities \& Social Studies, 2(5), 76-82

Olatunji, S.O., Aghimien, D.O., Oke, A.E. \& Olushola, E. (2016). Factors Affecting Performance of Undergraduate Students in Construction Related Disciplines. Journal of Education and Practice 7(13), 55-62

Osaikhiuwu, O.C., (2014). Institutional Factors Affecting the Academic Performance of Public Administration Students in a Nigerian university. Public Administration Research, 3(2), 171-177.

Osuji, J. N. (2016). Impact of School Facilities on Students' Academic Performances in Public Secondary Schools in Giwa and Zaria Education Zones, Kaduna State, Nigeria. Unpublished Dissertation Submitted to the School of Postgraduate Studies, Ahmadu Bello University, Zaria.

Rollnick, M., Davidowitz, B., Keane, M., Bapoo, A. \& Magadla, L. (2008). Students' learning-approach profiles in relation to their university experience and success. Teaching in Higher Education, 13(1), 29-42.

Smith, K. \& Hopkins, C. (2005). Great expectations: Sixth-formers' perceptions of teaching and learning in degree-level English. Arts and Humanities in Higher Education, 4(3), 304-318.

Steenkamp, L.P., Baard, R.S. \& Frick, B. (2009). Factors influencing success in first-year accounting at a South African university: A comparison between lecturers' assumptions and students' perceptions. South African Journal of Accounting Research, 23(1), 113-140.

Vasconcelos, R.M. \& Almeida, L.S. (2018). Academic Expectations for Engineering Freshmen: Gender differences. Paper Presented at the 2018 IEEE International Conference on Teaching, Assessment, and Learning for Engineering (TALE), 4-7 December 2018, Wollongong, NSW, Australia.

Irfan M. \& Shabana N. K. (2012). Factors Affecting Students' Academic Performance. Global Journal of Management and Business Research 12(9) 17-22

Omachonu, C.G. \& Akanya, J (2019) Effects of Social Media on the Academic Achievement of Students: A Case Study of the Students of the Department of Arts Education, Kogi State University, Anyigba, Nigeria. International Journal of English Language Teaching 7(5)14-23 